\title{
THE ROLE OF INFORMATION TECHNOLOGY IN ORGANIZATION DESIGN
}

\author{
Henry C. Lucas, Jr. \\ Jack Baroudi \\ Information systems Department \\ stern school of Business \\ New York University
}

Working Paper series

STERN IS-93-48

Forthcoming:

Journal of Management Information Systems (JMIS) 
The Role of Information Technology

in Organization Design ${ }^{1}$

\author{
Henry C. Lucas, Jr. \\ Jack Baroudi \\ Leonard N. Stern School of Business \\ New York University
}

\title{
ABSTRACT
}

This paper introduces a set of information technology variables which can be used in designing organizations. We first look at traditional design variables and then present a series of options enabled by modern information technology. We use these IT design variables to describe four prototypical organizationsn which are beginning to appear in the workplace: virtual, negotiated, traditional and vertically integrated. It is argued that an organization designer must also consider how structure and technology influence job tasks and people in order to be successful. The paper discusses potential implementation difficulties, particularly in motivating traditional

organizations to take advantage of IT design variables. The paper concludes that the design of information technology and the design of organizations is largely becoming the same task.

\section{INTRODUCTION}

The design of organizations is a fundamental management task. Mintzberg states the problem simply:

"Every organized human activity...gives rise to two fundamental and opposing requirements: the division of labor into various tasks to be performed and the coordination of these tasks to accomplish the activity. The structure of an organization can be defined simply as the sum total of the ways in which it divides its labor into distinct tasks and then achieves coordination among them([19]p.2).

Mintzberg's description of the design task is appealing because it is simple. In reality, there are a large number

\footnotetext{
${ }^{1}$ The authors would like to thank Professors Wanda Orlikowski and Daniel Robey for their insightful suggestions on this paper.
} 
of ways to divide labor and to coordinate tasks in the organization. There are various design strategies and variables that can be used in the organizational design process. For example, one design strategy is to encourage decentralized management. Top level managers delegate decision-making to local managers to have decisions made where a response to a problem is needed and to train lowerlevel managers in decision-making. An example of a design variable is the notion of span of control; how many individuals should report to a manager? This variable impacts other variables such as the number of levels of management in the organization.

Nadler and Tushman argue that changing organization design is a popular activity for senior managers because it is easy to alter the lines on an organization chart [20]. As we shall discuss later, it is much more difficult to change behavior, culture or strategy.

While much of the organizational design literature focuses on changing organizational structure, it is important to keep in mind that organization structure affects, and is affected by a number of other organizational constructs. For example, Leavitt has proposed a model of organizations which includes structure, people, tasks and technology (Figure 1) [13]. This is a useful framework because it makes clear that changes in the organization's structure may result in changes to tasks, technology and personnel and vice versa. One way to create structural changes may be by changing the technology in the organization. The relationship between changes in information technology and changes in organization form is the focus of this paper.

\section{PURPOSE}

The purpose of this paper is to discuss four prototypical organization designs or strategies that have emerged within certain industries and companies during the last two decades. These structures have been made possible by a group of new organizational design variables that are enabled by information technology (IT). The notion that information technologies could have a profound effect on organization structure is not new. As long ago as 1958, Leavitt and Whisler predicted significant changes in organizations as a result of new IT. They stated:

"Over the last decade [the 1950s] a new technology has begun to take hold in American business, one so new 
that its significance is still difficult to evaluate. While many aspects of this technology are uncertain, it seems clear that it will move into the managerial scene rapidly, with definite and far-reaching impact on managerial organization ([14]p. 41)."

Leavitt and Whisler in this article made numerous predictions regarding the form and shape of management in the 1980s. The accuracy of their predictions is of less interest than their prescience regarding the possibilities enabled by information technology, and their recognition that IT is substantially different from previous technologies.

Computers and information technologies have become frequently studied organization design variables [see for example, [2], [8], [9], [10] in the organizational research literature. For example, $\operatorname{Huber}[8,9,10]$ has focused on the impact of technology on organization design as reflected in decision processes. Blau et al. have examined organization structure and technology in manufacturing firms [2]. This research has been helpful in advancing our empirical and theoretical knowledge regarding information technology and organization structure, however, these studies did not examine outlier firms. It is our experience that it is the novel practices used by the more avant garde organizations which are pushing the boundaries of what is meant by organization.

We agree with Keen [12] that the basic assumptions of modern organization theory and practice such as the need to physically group people and units together to provide for coordination and supervision, or the need to choose between a centralized or decentralized structure, are being increasingly invalidated by IT. Many of the organizational possibilities enabled by information technology have either been overlooked or not well understood in the academic literature. In this paper, we attempt to fill this gap by describing how organizations can employ IT in novel ways to create ingenious organizational forms. We provide examples of firms that have done so. These companes are, in essence, the laboratories of organization design, and information technology is proving to be a key ingredient in their experiments. This paper is concerned with these firms. Existing literature on organizational design largely ignores the IT design variable discussed here.

The paper begins with a short review of past work on the impact of IT on organizational design. We then present a comparison of conventional and new, technology-based design variables. The paper proceeds to describe four prototypical 
organizations and how the design variables have helped facilitate these new design strategies. Our four prototypes are not intended to be exhaustive, but rather are illustrative of how organizations are evolving, both in terms of their use of technology and their organizational form.

\section{PREDICTIONS ABOUT IT AND ORGANIZATIONS}

It can be argued that many of Leavitt and Whisler's predictions have finally been realized [1]. Information technology gives managers options they have not had in the past. Companies have the benefit of small scale and large scale simultaneously and large organizations can become more flexible. Compared to classical organization structure, centralized and decentralized control merge as the firm focuses more on projects and processes than standard procedures and tasks. Keen [12] argues that organizations have reached the limits of complexity, but that IT can be used to reduce and manage this complexity.

Computers and communications have changed the relationship among firms and the structure of some existing companies like Frito Lay [16]; [22]). Frito-Lay has moved from a centralized organization to a "hybrid" organization in which lower levels of management concentrate on micromarketing. These changes were made possible by handheld computers for route drivers and an extensive corporate network to distribute data. As at Frito-Lay networks involving computers and communications devices foster more adhocracies and team-based organizations which overcome some of the limitations of traditional organizational hierarchies.

Other researchers are concerned with business process redesign, one of today's major trends in IT [3]. Process redesign, sometimes called reengineering, focuses on particular business processes and uses IT to make radical changes in these processes. Sometimes redesign requires changes in organizations such as creating a new structure across a process line. Reengineering, however, generally is concerned with isolated parts of a business rather than the design of an entire organization.

As will be seen, the work described above has influenced our definition of the IT variables presented later in the paper. 


\section{CLASSICAI ORGANIZATION DESIGN}

There are many classical works on organization design including the seminal book by March and Simon [17]. As articulated by Mintzberg. [19] in our introduction, a basic concern in much of the organizational design literature has been around how to organize and coordinate various tasks and workflows in the organization. Thompson [24], for example, focuses on three types of interdependencies betweeen work units: pooled, sequential, and reciprocal, and the demand for coordination that each creates.

In more recent work, Nadler and Tushman [20] describe four options for organizing work: by activity, by customer served, by output, or by multiple focus. Each of these arrangements has different coordination requirements. Mintzberg [19] looked at five components of an organization: the operating core, the strategic apex, the middle line, the technostructure, and the support staff. According to Mintzberg the structure of an organization is altered by adjusting how these components relate (coordinate) with each other or by altering the internal structure of a particular component.

In each of the above instances, coordination of activity and/or supervision is a critical variable. IT has had a major transformation effect on coordination as grouping tasks, functions or people together no longer requires physical proximity. Therefore, many of the organizational structures previously dictated by the need for physical proximity for coordination or production are no longer mandated. The beginnings of this idea can be found in Galbraith [5] who looked at information and its ability to reduce uncertainty. Using IT and various groupware technologies, the members of a department can be scattered throughout the world, but still have the feeling and experience of working closely with one another.

Much of the classical design literature takes a very rational view of the use of technology and the design of organizational form. We believe that organizational design is an emergent process [18] with the resulting organization form being the result of a complex and not altogether predictable interaction of both the technological and social environments. Given the difficulty of making precise predictions about how technology may affect structure, we believe much can be learned from looking at the organizational forms that are emerging in today's business 
environment. Understanding these new forms illustrates what is possible given current technology.

\section{NEW TECHNOLOGIES}

The organization designer has a set of variables to be used in creating or modifying an organization. An example of a variable is the definition of linking mechanisms; this variable has many possible values, e.g. the use of task forces, liaison agents, etc.

The problem with the conventional design literature reviewed above is its failure to recognize the new design variables that information technology enables. In the case of linking mechanisms, IT such as e-mail, Lotus Notes, or groupware may now play this role, making task forces or liaison agents unnecessary. Information technology (IT) is defined to include computers, communications, video conferencing, artificial intelligence, virtual reality, fax, cellular and wireless phones and pagers, etc.

The new IT enabled variables may be totally distinct from traditional design variables as is the case when virtual corporations are compared to traditional organizational subunits. IT enabled variables may also be an extension of a traditional variables, as in the case of developing linking mechanisms.

This section of the paper presents new organizational design variables enabled by information technology. We identified these variables through a review of the literature and trends in technology, innovative applications of IT, structural patterns in organizations, case studies and reports on reengineering business processes in the academic, trade and popular presses.

Table 1 arrays the conventional design variables drawn from the literature on organization design [2], [19], [20], [24] with new kinds of design variables enabled by information technology. The first column of the table groups conventional design variables into four categories: structural, work process, communications and interorganizational.

Column 4 in the table presents new organizational design variables made possible through information technology. These variables and their categories are: 
Structural

Virtual components: the organization can use IT to create components that in reality do not exist in conventional form. For example, some manufacturers want parts suppliers to substitute for their inventory. The supplier is linked through electronic data interchange with the manufacturer; using overnight delivery, it provides parts to the manufacturer just as they are needed for production. The manufacturer now has a virtual raw materials inventory which is owned by the supplier until it arrives for production.

Electronic linking: Through electronic mail, electronic or video conferencing and fax, it is possible to form links within and across all organizational boundaries. New work groups can be formed quickly and easily [26].

Technological leveling: IT can be substituted for layers of management and for a number of management tasks. In some bureaucratic organizations, layers of management exist to look at, edit and approve messages that flow from the layer below them to the level above. With electronic communications, some of these layers can be eliminated. In addition, a manager's span of control can be increased since electronic communications can be more efficient than phone or personal contact for certain kinds of tasks, particularly those dealing with administrative matters. Technology makes it possible to increase the span of control and possibly eliminate layers in the organization, leveling it in the process.

Work process

Production automation: the use of technology to automate manufacturing processes is well documented. IT has also been used extensively for automating information processing and assembly line tasks in the financial industry. In cases where information is the product of a firm, IT is the factory.

Electronic Workflows: interest in process reengineering has led to the development of work 
flow languages and systems. As organizations eliminate paper and perform most of their processing using electronic forms and images, workflow languages will be used to route documents electronically to individuals and work groups that need access to them.

Communications

\author{
Electronic Communications: Electronic mail, \\ electronic bulletin boards and Fax all offer \\ alternatives to formal channels of communications. \\ Technological matrixing: through the use of e- \\ mail, video and electronic conferencing and Fax, \\ matrix organizations can be created at will. \\ Interorganizational relations \\ Electronic customer/supplier relationships: \\ companies and industries are rapidly adopting \\ electronic data exchange (EDI) to speed the \\ ordering process and improve accuracy. \\ (For a more extensive treatment of \\ interorganizational issues, see the paper by \\ Kambil and short in this issue.)
}

\title{
NEW PROTOTYPICAL ORGANIZATIONS
}

It is possible to characterize four new organization structures that make use of the variables above to varying degrees. These prototypical organizations show a mixture of conventional and IT design variables and suggest some of the rich organization forms that will appear in the future. Table 2 shows each organization and how the IT design variables have made it possible to develop each type of organization. In some cases the IT variable has a substitution effect for traditional elements; in other cases it is necessary for the very existence of an organization form. In certain instances, the IT variable is optional or not applicable.

\section{Virtual Organizations}

Conventional organizations have historically organized workers together for purposes of communications and 
coordination. In contrast to physical presence, IT design variables allow for virtual organization structures. ${ }^{2}$

The virtual organization had its beginning 15 to 20 years ago as people began to see the possibilities of using technology for work at home [25]. With electronic communications capabilities, fax, e-mail and video conferencing, it is not clear that a physical organization is needed for many kinds of tasks.

For almost any organization that does not turn out a physical, durable product, one possible form would be an amalgamation of independent agents. Today, for example, many catalog operations use individuals working from their homes using a special phone connected to an 800 number.

Cruiser, an experimental system at Bell Communications Research, uses small video cameras, a central computer, and a window on a screen to allow users to visit colleagues' offices without leaving their desks [6]. If the promise of virtual reality is realized, it is possible to envision the use of "work helmets" to generate the image of a physical organization and a joystick to move around virtual office buildings to visit colleagues who are actually in many different locations. One could argue that with IT, there is no need to generate an office and the conventions that this entails. However, we feel that people will be more comfortable in the immediate future with the familiar metaphor of an office, even if it is in virtual form. In the more distant future, it is entirely possible the notion of an office may disappear; see the paper by Jarvenpaa and Ives in this issue for further discussion.

The virtual organization creates new management and coordination challenges. The kind of virtual office described above may be necessary to assuage a manager's misgivings about supervision. Perhaps all members of this non-organization will $\log$ in to virtual offices each morning to report in and have an electronic discussion with a supervisor. A step in this direction has already been taken by Jay Chiat, an advertising firm that has eliminated physical offices for many employees [21].

\footnotetext{
${ }^{2}$ The first use of the term "virtual" with respect to information technology was for a virtually infinite logical memory for time-sharing computers. A compiler broke a program into pages and stored the pages on disk. The logical memory of the computer appeared to be virtually infinite because disk space was so large compared to primary memory. A virutal organization uses IT to function like a traditional one.
} 


\section{Negotiated Organizations}

A flower company in California, Calyx and Carolla, is based on two negotiated agreements. The first agreement is with Federal Express to deliver flowers overnight to any destination in the US at a favorable rate. The second agreement is with flower growers; instead of selling exclusively to wholesalers, the growers agree to put together a number of standard arrangements.

The final part of the organization is an 800 number and clerks who take orders. The orders are sent via phone or Fax to growers who prepare and address arrangements for pick up and delivery by Federal Express. (Federal Express is also a leader in applying technology to handling overnight deliveries.)

Through these negotiated agreements and communications technology, this new company feels it can compete with the neighborhood florist and FTD. Prices are similar, and the flowers delivered overnight have been cut more recently than those found at the local florist. Calyx and Corolla is a negotiated organization in that its existence and profitability depends on the agreements it has with others, and the service supplied to its customers by others. Calyx and Corolla is, in effect, a broker using IT to coordinate its negotiated production facility and its negotiated delivery system.

The management challenge for the negotiated organization is to maintain service and quality. The firm depends on its partners to provide a product or service and yet has limited direct supervision of the business. Meeting service targets and deadlines and assuring adequate quality control can be difficult. As an example, the floral firm might place random orders with its growers to have flowers sent to its own management to test delivery time and product quality. Just as department stores have used "shoppers" for years to test their own personnel and service and to check on competition, the negotiated organization will need the equivalent of "electronic shoppers."

\section{Traditional Organizations}

Traditional organizations are using technology to make some changes in structure without making major modifications to the entire organization. An electronics manufacturer has set up a just-in-time EDI link with a parts supplier, changing one component of the organization; the supplier can 
now be viewed as part of the manufacturer's raw material inventory.

The traditional organization may call its redesign efforts "reengineering." A major brokerage firm, for example, has completely redesigned the way it processes physical securities turned over to it by customers. This redesign has resulted in the closing of two processing centers and the creation of a new site for processing. The firm has adopted image processing to dramatically reduce the need to physically handle securities. The total number of individuals employed in handling securities has been cut by $50 \%$ in this process redesign.

There are many examples of the use of IT design variables to make changes in parts of traditional organizations. A management challenge in the traditional organization is to be able to transform the organization enough so that it can take advantage of the cost savings and competitive opportunities made possible by technology. The objective of process reengineering is to make dramatic improvements in how an organization functions.

The traditional organization may need to move toward a more virtual model to improve its responsiveness. Today's business environment is characterized by rapid changes; slow moving companies are at a major disadvantage. At a minimum, the traditional organization needs to take advantage of technological leveling to reduce layers of management, electronic matrixing to improve coordination, and electronic workflows to reduce paper handling.

The traditional organization today is at risk; IBM, one of the largest and most admired "blue chips" in the 1960 s and 1970s, is struggling with declining market share and bureaucracies that resist the kind of sweeping changes needed to be competitive. IT organization design variables can help restructure traditional organizations making them more flexible. However, bringing about the kind of changes that are possible given the technology is a formidable management challenge that we discuss further below.

\section{Vertically Integrated Conglomerates}

The movement toward greater exchange of data electronically between customers and suppliers may be creating cases of vertically integrated conglomerates. The tendency for this form to emerge will be greater if there is a large power imbalance between the customer and the supplier. 
As an example, General Motors requires virtually all of its suppliers to use EDI. For some suppliers, GM accounts for such a large proportion of their business that the supplier virtually becomes a component of GM, responding to its orders and demands. GM sends orders to the supplier's own production scheduling system and is permitted to modify production schedules, priorities, etc. The supplier has virtually become a part of the large, electronic conglomerate that exists around GM.

Especially for the small supplier, GM has obtained a substantial amount of control for little or no investment. GM can sever the relationship at any time at almost no cost to itself. It is not clear that vertically integrated conglomerates are a desirable model for many organizations.

It should be made clear that managers must be careful when establishing electronic links; they are very appealing from an efficiency standpoint. However, they can lock a firm into a relationship that reduces its independence. To the extent that the links are standardized, for example using an industry standard or an X.12 EDI protocol, firms involved have more flexibility in switching business relationships. If a link goes beyond simple exchange transactions and actually gives a customer access to one's production planning systems, then the supplier risks becoming a part of a vertically integrated conglomerate for better or for worse.

\section{ADDING PEOPLE AND TASKS}

At this point, it is useful to consider again Leavitt's model in Figure 1. In addition to structure and technology, an organization consists of people and tasks. As some of the examples above show, it may be difficult to change an organization if one only attempts to alter its structure: people and tasks may create the greatest challenge for the organization designer.

Table 3 adds people and tasks to structure and technology and provides a more complete picture for the organizational designer. The first three organizations in the table are conventional and show typical assumptions about people and task structuring along with examples.

In a rigidly hierarchical organization tasks are separated and decision-making tends to be highly routinized. Tasks are defined by rules and practice, and risk is 
avoided. An adhocracy, on the other hand, is based on trust and professional conduct; for example, members of law and consulting firms tend to define their own tasks.

There can be many assumptions about people and task designs for the four prototype firms discussed in this paper. In Table 3, we describe the assumptions about people and tasks that seem likely for these four types. For more information on questions of trust and professionalism in new organizational forms, see [4].

The virtual organization has to be based on trust and minimal supervision because it is very difficult to supervise and control its components. We expect that this type of organization will be more common in the future as a number of forces, from child-care to air pollution concerns, argue for fewer, centralized workplaces given the commuting such a workplace necessitates.

In a negotiated organization, one must trust employees who are in allied companies. An agreement may specify the required output or level of service, but it will be up to each member of the alliance to accomplish its tasks as it sees fit.

The traditional firm with electronic components tends to be large and will treat its employees in a variety of ways. There may be a tendency toward bureaucracy and defining tasks for lower level employees. Technology can be used to distribute responsibility to lower level managers, or to centralize control over the organization; it all depends on the firm's assumption about employees and how it defines tasks, especially decision-making.

The vertically integrated electronic conglomerate is very control-oriented as it drives the systems of a different organization; it avoids the expense, the need for and the risks of traditional vertical integration. As a result, it tends to specify clearly how the firms connected to it electronically must operate.

\section{THE IMPLEMENTATION CHALLENGE}

Scott Morton [23] also points out the need for changes in management and organization structure to take advantage of the potential of information technology. It appears easiest to use IT variables to design new organizations like Calyx and Carolla; there is no existing structure or culture which has to be changed. Companies like Mrs. Field's Cookies have created parts of their firms with flat organization structures using several of the variables described in this 
paper. Through the use of technology to collect store data and report results, store controllers at headquarters monitor from 35 to 75 stores each.

However, Mrs. Fields did not have an entrenched structure and culture populated by managers with a vested interest in maintaining the status quo. To bring about the kind of major change these firms need will take a significant effort.

If a virtual organization is new, it should also be relatively easy to design. Although workers comfortable in a traditional workplace may find such an arrangement difficult to understand at first. For organizations creating virtual subunits which currently exist in reality, or for traditional organizations trying to redesign some of their components, the use of IT in organization design will be much more difficult.

While it is easy for authors to describe and call for sweeping new kinds of organizations [23], [16], the reality of moving to these new forms is a different story. There have been isolated reports of success in reengineering [3], but these efforts have concentrated on only a small part of a firm's activities like the accounts payable section at Ford [7]. How does one get IBM, GM and DEC to use IT to undertake a major redesign of their organizations?

There are few examples of massive change programs that have been successful in the literature. Kearns and Nadler [11] have reported on their efforts to refocus Xerox on quality as the underlying focus of business. Their change program involved off-site seminars in which employees participated once as students and a second time as instructors. Despite this double exposure to the program, a number of employees still did not believe management was serious about the change. Kearns and Nadler do not present cost data, but the multi-year program they described represented a significant investment with significant senior level management support in refocusing the organization. The results were partially responsible for revitalizing a company that Kearns, on becoming chairman, was convinced might not survive.

We do not believe that isolated departmental restructurings, for example, creating a single virtual work group, will spread quickly enough to the rest of the organization to create significant structural changes. If a traditional organization wants to take advantage of the opportunities for new organizational forms offered by the IT 
design variables described here, it will have to undertake a massive change effort that is lead by senior management.

What conditions will motivate management to redesign the organization and to use IT in the process? There are a number of events which are likely to stimulate change.

1. A merger or acquisition,

2 A major crisis such as a record loss,

3. Bankruptcy,

4. A rebellion by the board of directors,

5. A legal or regulatory reversal.

It would be better if management recognized the need for change before a crisis and devoted resources to restructuring the organization. The recent history of major firms experiencing significant difficulties, however, does not inspire optimism. Creating the organization changes required to take advantage of the new structures made possible by information technology may be management's biggest challenge as we move into a new century.

\section{CONCLUSIONS}

Conventional organization design variables have been used for hundreds of years. Some would argue that they have served organizations well. As competition becomes more intense, organizations will have to react more quickly to environmental change and to competitors. Organization designs that result in hierarchies, bureaucracies and many levels of review and approval seem to be incapable of fast response. Information technology offers additional variables that, when combined with considerations of structure, people and tasks, can help design more responsive organizations. However, it will be difficult, and in some instances virtually impossible, to move a traditional organization to adopt new structures that take advantage of IT design variables.

For any organization, in the future, it is likely that the tasks of technology design and organization design will become even more closely intertwined. We believe that 1) the design of information technology is the design of organizations and that 2)organizational designers should take advantage of the IT enabled variables described here 
for designing new organizations. In the final analysis, the organization of the future may not be an organization at all.

\section{REFERENCES}

[1] Applegate, L., J. Cash and Mills, "Information technology and tomorrow's manager, Harvard Business Review (November-December 1988), pp. 126-136.

[2] Blau, P.M. , C. Falbe, W. McKinley and P. Tracy, "Technology and organization in manufacturing," Administrative Science Quarterly, Vol. 21, (March, 1976), pp. 20-39.

[3] Davenport, T. and J. Short, "The new industrial engineering: information technology and business process redesign," Sloan Management Review, Vol. 31, No. 4, (Summer 1990), pp. 11-27.

[4] Drucker, "The coming of the new organization," Harvard Business Review, 1988, pp.

[5] Galbraith, J. Organization Design, Reading: AddisonWesley, 1977.

[6] Fish, R., R. Kraut, R. Root and R. Rice, "Video as a technology for informal communication, Communications of the ACM, Vol. 36, No. 1 (January 1993), pp. $48-61$.

[7] Hammer, M., "Reengineering work: don't automate, obliterate," Harvard Business Review, (July-August), 1980, pp. 104-112.

[8] Huber, G., "The Nature and design of post-ndustrial organizations," Management Science, Vol 30, (1984), pp. 928951.

[9] Huber, G., "Effects of decision and communication technologies on organizational decision processes and structures. In R. M. Lee, A. McCosh \& P. Migliatrese (eds.) Organization Decision Support Systems, Amsterdam: NorthHolland, 1988 (pp. 317-333.) 
[10] Huber, G., "A Theory of the effects of advanced information technologies on organizational design, Intelligence, and Decision Making," Academy of Management Review, Vol. 15, No. 1 (1990), pp $47 .-71$.

[11] Kearns, D. and D. Nadler, Prophets in the Dark, New York: HarperCollins, 1992.

[12] Keen, P. Shaping the Future: Business Design Through Information Technology, Boston: Harvard Business School Press, 1991.

[13] Leavitt, H. "Applied organizational change in industry," in J. March, (ed) Handbook of Organizations, Chicago: Rand McNally, 1965.

[14] Leavitt, H. and T. Whisler, "Management in the 1980's," Harvard Business Review (November-December), 1958, pp 41-48.

[15] Lucas, Henry C., Jr., M. Ginzberg and R. Schultz, Information systems Implementation: testing a Structural Model, Norwood, N.J.: Ablex, 1990.

[16] Malone, T. M. and J. F. Rockart, "Computers, networks and the corporation," Scientific American, September, 1991, $\mathrm{pp}$.

[17] March, J. and H. Simon. Organizations, New York, John Wiley, 1958 .

[18] Marcus, L. and D. Robey, "Information technology and o organizational change: causal structure in theory and research," Management Science, Vol 34, No. 5 (May 1988) pp. 583-598

[19] Mintzberg, H. The Structuring of Organizations, Englewood Cliffs: Prentice-Hall, 1979.

[20] Nadler, D., and M. Tushman. Strategic Organization Design, HarperCollins, 1988.

[21] The New York Times, "The Virtual office becomes reality", October 28, 1993.

[22] Rochart, J. and J. Short, "The Networked organization and the management of interdependence," in M. Scott Morton (ed.), The Corporation of the 1990s, London, Oxford University Press, 1991.

[23] Scott Morton, M. (ed.), The Corporation of the 1990s, London, Oxford University Press, 1991. 
[24] Thompson, J. Organizations in Action, New York: McGrawHill, 1967.

[25] Venkatesh, A., and N. Vitalari, "An Emerging Distributed Work Arrangement: An Investigation of computerbased supplemental work at home," Management Science, Vol. 38, No. 12 (December 1992), pp. 1687-1706.

[26] Vincent, D. The Information-Based Corporation, Homewood, Il: Dow Jones-Irwin, 1990. 


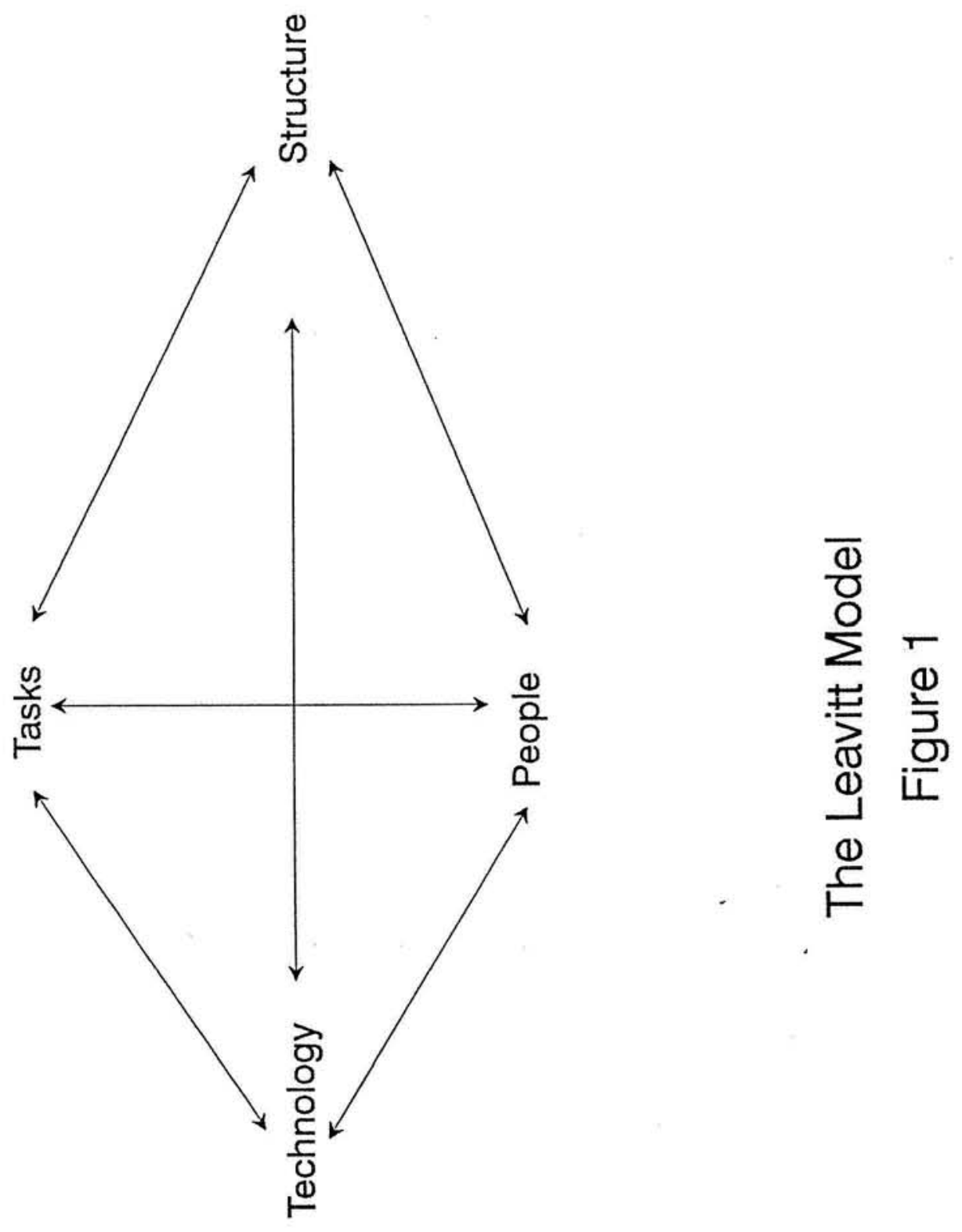


Class of Variable Structural

Work Process

Interorganizational relations

\begin{tabular}{|c|c|c|}
\hline $\begin{array}{l}\text { Conventional } \\
\text { Design Variables }\end{array}$ & Source & $\begin{array}{l}\text { IT Design } \\
\text { Variables }\end{array}$ \\
\hline Definition of & Nadler and & virtual \\
\hline $\begin{array}{l}\text { organizational } \\
\text { subunits }\end{array}$ & $\begin{array}{l}\text { Tushman; } \\
\text { Galbraith; Thomp- } \\
\text { son }\end{array}$ & components \\
\hline Determining & Nadler and & \\
\hline purpose, output & Tushman; & \\
\hline of subunits & $\begin{array}{l}\text { Galbraith; } \\
\text { Thompson }\end{array}$ & \\
\hline $\begin{array}{l}\text { Reporting } \\
\text { mechanisms }\end{array}$ & $\begin{array}{l}\text { Nadler and } \\
\text { Tushman; } \\
\text { Mintzberg }\end{array}$ & \\
\hline Linking & Galbraith; & Electronic \\
\hline mechanisms & $\begin{array}{l}\text { Nadler and } \\
\text { Tushman }\end{array}$ & linking \\
\hline $\begin{array}{l}\text { Control } \\
\text { mechanisms }\end{array}$ & $\begin{array}{l}\text { Nadler and } \\
\text { Tushman }\end{array}$ & \\
\hline Staffing & Mintzberg & $\begin{array}{l}\text { Technological } \\
\text { leveling }\end{array}$ \\
\hline Tasks & $\begin{array}{l}\text { Nadler and } \\
\text { Tushman }\end{array}$ & $\begin{array}{l}\text { Production } \\
\text { automation }\end{array}$ \\
\hline Work flows & $\begin{array}{l}\text { Nadler and } \\
\text { Tushman }\end{array}$ & $\begin{array}{l}\text { Electronic work } \\
\text { flows }\end{array}$ \\
\hline Dependencies & Thompson & \\
\hline $\begin{array}{l}\text { Output of } \\
\text { process }\end{array}$ & & \\
\hline Buffers & Galbraith & $\begin{array}{l}\text { Virutal } \\
\text { components }\end{array}$ \\
\hline Formal channels & Mintzberg & $\begin{array}{l}\text { Electronic } \\
\text { communications }\end{array}$ \\
\hline $\begin{array}{l}\text { Informal } \\
\text { communications/ } \\
\text { collaboration }\end{array}$ & Mintzberg & $\begin{array}{l}\text { Technological } \\
\text { matrixing }\end{array}$ \\
\hline $\begin{array}{l}\text { Make versus buy } \\
\text { decision }\end{array}$ & & $\begin{array}{l}\text { Electronic } \\
\text { customer/ } \\
\text { supplier relat- } \\
\text { ionships }\end{array}$ \\
\hline $\begin{array}{l}\text { Exchange of } \\
\text { materials }\end{array}$ & & $\begin{array}{l}\text { Electronic } \\
\text { customer/ } \\
\text { supplier relat- } \\
\text { ionships }\end{array}$ \\
\hline $\begin{array}{l}\text { Communications } \\
\text { mechanisms }\end{array}$ & Mintzberg & $\begin{array}{l}\text { Electronic } \\
\text { linking }\end{array}$ \\
\hline
\end{tabular}




\begin{tabular}{|c|c|c|c|c|}
\hline & Virtual & $\begin{array}{l}\text { Negotiated } \\
\text { Organizat- } \\
\text { ions }\end{array}$ & $\begin{array}{l}\text { Tradition- } \\
\text { al }\end{array}$ & $\begin{array}{l}\text { Vertically } \\
\text { integrated } \\
\text { conglomer- } \\
\text { ates }\end{array}$ \\
\hline $\begin{array}{l}\text { Virtual } \\
\text { components }\end{array}$ & $\begin{array}{l}\text { Substitute } \\
\text { electronic } \\
\text { for } \\
\text { physical } \\
\text { components }\end{array}$ & $\begin{array}{l}\text { Substitute } \\
\text { electronic } \\
\text { for } \\
\text { physical } \\
\text { components }\end{array}$ & $\begin{array}{l}\text { Use to } \\
\text { replace } \\
\text { isolated } \\
\text { components }\end{array}$ & $\begin{array}{l}\text { Force } \\
\text { component } \\
\text { onto } \\
\text { electronic } \\
\text { subsidiary }\end{array}$ \\
\hline $\begin{array}{l}\text { Electronic } \\
\text { linking } \\
\text { and } \\
\text { communicat } \\
\text { ions }\end{array}$ & $\begin{array}{l}\text { Essential } \\
\text { part }\end{array}$ & $\begin{array}{l}\text { Essential } \\
\text { part }\end{array}$ & Optional & $\begin{array}{l}\text { Essential } \\
\text { part }\end{array}$ \\
\hline $\begin{array}{l}\text { Technologi } \\
\text { cal } \\
\text { matrixing }\end{array}$ & $\begin{array}{l}\text { Partici- } \\
\text { pate in } \\
\text { matrixed } \\
\text { group }\end{array}$ & $\begin{array}{l}\text { Use for } \\
\text { coordinat- } \\
\text { ion }\end{array}$ & $\begin{array}{l}\text { Use for } \\
\text { various } \\
\text { groups }\end{array}$ & $\begin{array}{l}\text { Use for } \\
\text { coordinat- } \\
\text { ion and } \\
\text { task } \\
\text { forces }\end{array}$ \\
\hline $\begin{array}{l}\text { Technologi } \\
\text { cal } \\
\text { leveling }\end{array}$ & $\begin{array}{l}\text { Use to } \\
\text { supervise } \\
\text { remote } \\
\text { workers } \\
\text { and } \\
\text { groups }\end{array}$ & $\mathrm{NA}$ & $\begin{array}{l}\text { Use to } \\
\text { reduce } \\
\text { layers of } \\
\text { management }\end{array}$ & $\begin{array}{l}\text { Use to } \\
\text { reduce } \\
\text { layers of } \\
\text { management }\end{array}$ \\
\hline $\begin{array}{l}\text { Electronic } \\
\text { workflows }\end{array}$ & $\begin{array}{l}\text { Crucial } \\
\text { part of } \\
\text { strategy }\end{array}$ & $\begin{array}{l}\text { Crucial } \\
\text { part of } \\
\text { strategy }\end{array}$ & $\begin{array}{l}\text { Use where } \\
\text { applicable } \\
\text { to re- } \\
\text { structure } \\
\text { work }\end{array}$ & $\begin{array}{l}\text { Key to } \\
\text { coordinat- } \\
\text { ing work } \\
\text { units }\end{array}$ \\
\hline $\begin{array}{l}\text { Production } \\
\text { automation }\end{array}$ & $\mathrm{NA}$ & $\begin{array}{l}\text { Communi- } \\
\text { cate } \\
\text { designs }\end{array}$ & $\begin{array}{l}\text { Use where } \\
\text { applicable }\end{array}$ & $\begin{array}{l}\text { Coordinate } \\
\text { production } \\
\text { among work } \\
\text { units }\end{array}$ \\
\hline $\begin{array}{l}\text { Electronic } \\
\text { customer/ } \\
\text { supplier } \\
\text { links }\end{array}$ & $\begin{array}{l}\text { Used } \\
\text { extensive- } \\
\text { ly }\end{array}$ & $\begin{array}{l}\text { Used } \\
\text { extensive- } \\
\text { ly }\end{array}$ & $\begin{array}{l}\text { Potential- } \\
\text { ly } \\
\text { important }\end{array}$ & $\begin{array}{l}\text { Key to } \\
\text { operations }\end{array}$ \\
\hline
\end{tabular}

IT Design Variables

and Four Prototypical Organizations

Table 2 


\begin{tabular}{|l|l|l|l|}
\hline $\begin{array}{l}\text { Structure and } \\
\text { technology } \\
\text { (grouping, } \\
\text { tasks, jobs, linkages) }\end{array}$ & $\begin{array}{l}\text { People } \\
\text { Assumptions about } \\
\text { motivation }\end{array}$ & $\begin{array}{l}\text { Tasks } \\
\text { Especially decision- } \\
\text { making }\end{array}$ & Example \\
\hline $\begin{array}{l}\text { Rigid } \\
\text { hierarchy }\end{array}$ & $\begin{array}{l}\text { People need external } \\
\text { motivation }\end{array}$ & $\begin{array}{l}\text { No delegation; tasks } \\
\text { designed for employee }\end{array}$ & $\begin{array}{l}\text { Military } \\
\text { organizat- } \\
\text { ions }\end{array}$ \\
\hline $\begin{array}{l}\text { Bureau- } \\
\text { cracy }\end{array}$ & $\begin{array}{l}\text { People want direction, } \\
\text { procedures, are not good } \\
\text { decision-makers }\end{array}$ & $\begin{array}{l}\text { Limited delegation and } \\
\text { decision authority }\end{array}$ & $\begin{array}{l}\text { Government } \\
\text { University } \\
\text { (administration) }\end{array}$ \\
\hline Adhocracy & $\begin{array}{l}\text { Trust, } \\
\text { professionalism }\end{array}$ & $\begin{array}{l}\text { Loosely defined; individ- } \\
\text { ual decides how to } \\
\text { best accomplish tasks }\end{array}$ & $\begin{array}{l}\text { Law firm } \\
\text { University (faculty) }\end{array}$ \\
\hline $\begin{array}{l}\text { Virtual } \\
\text { Trust } \\
\text { self-control }\end{array}$ & $\begin{array}{l}\text { Trust in } \\
\text { partners/ } \\
\text { alliances }\end{array}$ & $\begin{array}{l}\text { Basic tasks defined in } \\
\text { agreement; details left to } \\
\text { individuals }\end{array}$ & $\begin{array}{l}\text { Oalyx \& Carolla flower } \\
\text { company } \\
\text { future? }\end{array}$ \\
\hline $\begin{array}{l}\text { Negotiated } \\
\text { agreement }\end{array}$ & $\begin{array}{l}\text { Mixed, some suspicion } \\
\text { and self-control } \\
\text { assumed }\end{array}$ & $\begin{array}{l}\text { Tendency to define } \\
\text { tasks for lower-level } \\
\text { employees; some } \\
\text { discretion for managers }\end{array}$ & IBM \\
\hline $\begin{array}{l}\text { Traditional } \\
\text { with } \\
\text { electronic } \\
\text { components }\end{array}$ & $\begin{array}{l}\text { Tasks tend to be designed } \\
\text { for employee, even those } \\
\text { in linked organizations }\end{array}$ & $\begin{array}{l}\text { GM } \\
\text { Vertically integrated } \\
\text { conglomerates } \\
\text { organizations expendablentation; }\end{array}$ & \\
\hline
\end{tabular}

Additional Design Variables
Table 3 